\title{
Joanna Nawrocka, Społeczne doświadczenie starości: stereoty- py, postawy, wybory, Oficyna Wydawnicza IMPULS, Kraków 2013, ss. 136
}

Książka autorstwa Joanny Nawrockiej zatytułowana Społeczne doświadczenie starości: stereotypy, postawy, wybory została wydana w 2013 roku w Krakowie przez Oficynę Wydawniczą ,Impuls”. Autorka podejmuje w niej problematykę starości. Na książkę składają się trzy następujące rozdziały: Czy stara osoba jest starq kobieta, czy starym mężczyzną?, Postawy wobec ludzi starych oraz Młodzi, starsi, starzy - miłość i satysfakcja z życia.

$\mathrm{Na}$ wagę i aktualność podjętej problematyki wskazuje Autorka we wprowadzeniu. Wstęp niewątpliwie zachęca do lektury książki, ukazując jednocześnie uzasadnienie wyboru eksplorowanej tematyki. Doktor Nawrocka podkreśla, że edukacja społeczeństwa w zakresie gerontologii i psychologii społecznej jest warunkiem koniecznym w skutecznym radzeniu sobie z wyzwaniami starości.

Pierwszy rozdział opisuje badania odnoszące się do społecznego postrzegania seniorów ogółem oraz starszych kobiet i starszych mężczyzn. Na podstawie analizy Autorka wyodrębniła cztery czynniki w modelu określającym osoby starsze. Są to: starczość, destrukcja starości, szlachetność oraz zniedołężnienie i wykluczenie. Tekst przedstawia także pogłębioną analizę między poszczególnymi czynnikami a określonymi zmiennymi demograficznymi. Na wagę podjętego działania badawczego wskazuje duża liczba respondentów (807 osób). Należy również zaznaczyć, iż opracowanie to wykracza poza dotychczasową eksplorację kwestii stereotypów dotyczących seniorów.

Kolejna część odnosi się do postaw wobec ludzi starych. Rozdział ten zawiera treści dotyczące ageizmu, telewizyjnej transmisji negatywnych stereotypów związanych ze starością oraz postaw pozytywnych w stosunku do seniorów. Autorka podkreśla, iż złożoność postaw zależy od różnorod- 
nych czynników, które zawsze oddziałują w przestrzeni społecznej. Także ta część książki ukazuje wyniki badań przeprowadzonych na dużej grupie osób (s. 449). Analiza danych pokazuje trzy główne czynniki określające postawy wobec starości: sprzyjanie potencjałowi, a także wrogie i realistyczne nastawienie.

Trzeci rozdział jest niezwykle wartościowym ukazaniem tematu miłości oraz satysfakcji z życia. Został on napisany przez Joannę Nawrocką, Elżbietę Nawrocką i Julię Kamińską. Po przedstawieniu przeglądu literatury Autorki prezentują wyniki badań uzyskane za pomocą trzech narzędzi, do których należały: Kwestionariusz Satysfakcji z Partnera i Związku, Skala Postaw Wobec Miłości i Skala Satysfakcji z Życia. Analiza danych pozwoliła na odkrycie ciekawych zależności między poczuciem satysfakcji ze związku a satysfakcją z życia, jak również korelacji między długością związku a preferowanym rodzajem miłości. Bardzo interesującym jest fakt, że artykuł przeczy potocznym przekonaniom, że seniorzy chcą trwać w pełnych poświęceń związkach. Okazuje się, że wolą oni relacje, które dają radość, ekscytację oraz odmłodnienie. Tym samym opracowanie to niewątpliwie daje szerszy pogląd na temat miłości odnoszonej do seniorów.

Recenzowana książka porusza bardzo ważny problem współczesnego społeczeństwa, jakim jest opieka nad niesprawnymi seniorami oraz wielkie obciążenie ich opiekunów. To wymagające i wyczerpujące zajęcie obciąża niemal wyłącznie rodzinę. Autorka w sposób generalizujący (co jest pewnym zarzutem) podaje, że opieka ta ,spada na kobiety w fazie średniej dorosłości” (s. 9). Wprawdzie stanowią one większość domowych opiekunów, jednak nie są nimi wyłącznie. W sytuacji zajmowania się zniedołężniałymi rodzicami stają się one (lub oni) pielęgniarkami-opiekunkami, pracującymi przez całą dobę siedem dni w tygodniu. Rodzi to różne negatywne konsekwencje, takie jak przemęczenie czy wręcz wyczerpanie, a także pogarszający się stan zdrowia.

Ostatnie części książki - konkludujące zakończenie, bogata bibliografia, schematy, tabele, wykresy i załączniki - dopełniają całości recenzowanego tekstu. Na końcu zostały umieszczone narzędzia badawcze oraz dane przedstawiające poszczególne etapy procesu badania. Wspomniane załączniki zostały włączone do tekstu przez Autorkę z myślą o studentach, aby zachęcić ich do eksploracji problemu starości.

Uważam, że książka Joanny Nawrockiej jest kompetentnie napisaną pracą, stanowiącą bogate źródło rzetelnych i jednocześnie interesujących danych. Opracowanie zostało starannie przygotowane zarówno pod względem językowym, jak i edytorskim. Na uwagę zasługuje struktura tekstu, 
która charakteryzuje się wysokim stopniem przejrzystości, przez co jest bardziej przystępna dla czytelnika. Pomimo iż trzy rozdziały stanowią odrębne artykuły, razem nakreślają szerokie tło dla analiz i rozważań nad kwestią starzenia się oraz starości. Niewątpliwie książka ta jest udanym opracowaniem, które wzbogaci wiedzę studentów, osób ze świata nauki oraz innych czytelników zainteresowanych tak istotną problematyką, jaką jest starość.

Katarzyna Sygulska 